\title{
GASTRIC ACIDITY IN NORMAL INDIVIDUALS
}

\author{
By J. LERMAN, F. D. PIERCE AND A. J. BROGAN \\ (From the Medical Clinic of the Massachusetts General Hospital, Boston)
}

(Received for publication August 13, 1931)

A review of the literature reveals comparatively little information concerning gastric acidity in normal individuals. The available data are based mostly on test meals of the Ewald type. In addition to the technical difficulties in analysis inherent in these methods, they fail to give a maximum stimulation for secretion of gastric juice, as do histamine or histamine plus alcohol. Consequently the average acidities of the available standards are low and the incidence of achlorhydria high. As demonstrated by Gompertz and Vorhaus (1) and Bockus and Bank (2) histamine used in conjunction with the test meal enables one to differentiate true from false achlorhydria. Thus Davies and James (3), studying normal persons over the age of 60 , and Vanzant (4) investigating a large series of normals of all ages, have made use of this means of differentiating true from false achlorhydria. Except for the recently published data of Polland and Bloomfield (5), we have been unable to find any normal gastric acidity standards based on histamine as the gastric secretory stimulant. An objection to their results may be raised, namely, they do not contain figures for the incidence of achlorhydria.

Because of the lack of suitable data concerning the gastric acidity of the normal individual it was deemed advisable to collect our own from the hospital records before proceeding with our study of the gastric secretion in various pathological conditions. We are placing these on record, with the hope that they may be of value to those who use the technique of gastric analysis similar to ours.

\section{METHOD}

The gastric contents were obtained in the morning after a 12 hour fasting period. A gastric tube was introduced through the nose and the fasting contents removed. This was followed by the subcutaneous injection of $0.5 \mathrm{mgm}$. ergamine acid phosphate (histamine) and the administration through the tube of $50 \mathrm{cc}$. of 7 per cent alcohol. Samples of gastric contents were drawn at half hour and one hour intervals, all of the contents being removed with the last sample. The volume, and the free and total acidity of each sample were determined, using Töpfer's reagent and phenolphthalein as the indicators in the titration of the respective acidities. In addition, the gross physical characteristics and the presence 
of occult blood were recorded. All analyses were made by various members of the resident medical staff.

We have concerned ourselves mainly with the free and total acidity and their correlation with age, sex, red blood cell count and hemoglobin content. In making the tables and charts we used the maximum acidity obtained following stimulation with histamine and alcohol. In the case of the red blood cell count and hemoglobin content, the average values were taken.

The measurements of volume were considered too inaccurate to furnish any useful information.

We did not use the method of continuous withdrawal of gastric contents at 10 minute intervals as advocated by Polland, Roberts and Bloomfield (6). The use of alcohol plus histamine makes our data incomparable to those of Polland and Bloomfield (5) based on histamine alone, but our data are more comparable to those of Vanzant (4), based on a test meal of crackers and water, and histamine in cases of achlorhydria. The alcohol test meal has the additional advantage of meeting the criticisms offered by Henning (7) and by Comfort and Osterberg (8), namely, that certain cases fail to secrete free acid with histamine but do so with a test meal.

\section{MATERIAL}

The records of all patients having had gastric analyses during the years 1928-1930 inclusive were examined. Out of a total of 720 records, 200 were selected as representing normal individuals. All persons suffering from any disease which might possibly affect gastric secretion were excluded from this series of cases. In addition, the absence of severe gastro-intestinal symptoms, roentgenological examination of the gastro-intestinal tract and Graham test and a relatively negative physical examination were required before a patient was considered normal. ${ }^{1}$

Most of the 200 cases were in the age groups of 20-69, fairly uniformly distributed. There were 5 under 20 years of age, and 5 over 70 . There were 90 males and 110 females. The results for free and total acidity in relation to age are tabulated in Tables 1 and 2 . The normal acidity range was considered to be $20-70 \mathrm{cc}$. for free acid and 10 points higher for total acid.

The average free acidity was $40.4 \mathrm{cc}$. of 0.1 normal acid per $100 \mathrm{cc}$. There was a fluctuation in the age groups between $36.8 \mathrm{cc}$. and $57.8 \mathrm{cc}$, but no definite relation to age. The total acidity ranged approximately 10 points higher, the average being $50.1 \mathrm{cc}$. On calculating the coefficients of correlation between age and gastric acidity, we found the results to be

1 There were a number of doubtful cases which were examined very carefully with the help of Dr. Chester M. Jones before they were included as normals or rejected. 
TABLE 1

Distribution by age of the free acidity of 200 normal subjects

\begin{tabular}{|c|c|c|c|c|c|c|c|c|}
\hline \multirow{2}{*}{ Cc. $0.1 \mathrm{~N} \mathrm{HCl}$} & \multicolumn{7}{|c|}{ Age (Years) } & \multirow{2}{*}{ Total } \\
\hline & -20 & $20-29$ & $30-39$ & $40-49$ & $50-59$ & $60-69$ & $70+$ & \\
\hline 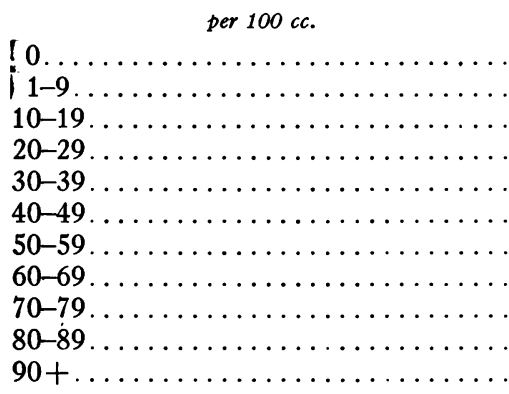 & $\begin{array}{l}1 \\
1 \\
2 \\
1\end{array}$ & \begin{tabular}{c|} 
cases \\
1 \\
1 \\
2 \\
4 \\
2 \\
4 \\
3 \\
2 \\
2 \\
1 \\
1
\end{tabular} & $\begin{array}{c}\text { cases } \\
5 \\
2 \\
5 \\
4 \\
6 \\
5 \\
5 \\
2 \\
1 \\
5\end{array}$ & $\begin{array}{c}\text { cases } \\
4 \\
2 \\
4 \\
3 \\
5 \\
7 \\
3 \\
3 \\
5 \\
1 \\
3\end{array}$ & $\begin{array}{c}\text { cases } \\
10 \\
4 \\
5 \\
7 \\
1 \\
2 \\
5 \\
4 \\
5 \\
4 \\
4\end{array}$ & $\begin{array}{c}\text { cases } \\
6 \\
2 \\
4 \\
3 \\
3 \\
4 \\
3 \\
5 \\
3 \\
2 \\
1\end{array}$ & $\begin{array}{c}\text { cases } \\
1 \\
1\end{array}$ & $\begin{array}{r}\text { cases } \\
26 \\
12 \\
21 \\
22 \\
17 \\
23 \\
21 \\
16 \\
18 \\
13 \\
11\end{array}$ \\
\hline Total $\ldots \ldots \ldots \ldots \ldots \ldots \ldots$ & 5 & 23 & 40 & 40 & 51 & 36 & 5 & 200 \\
\hline Average acidity ... & 50.2 & 43.3 & 36.8 & 42.4 & 38.7 & 38.8 & 57.8 & \\
\hline Average of 174 cases with free acid... & 50.2 & 45.3 & 42.1 & 47.1 & 48.1 & 46.6 & 57.8 & \\
\hline
\end{tabular}

Standard deviation of acidity $=28.4$

Standard deviation of age $\quad=14.3$

TABLE 2

Distribution by age of the total acidity of 200 normal subjects

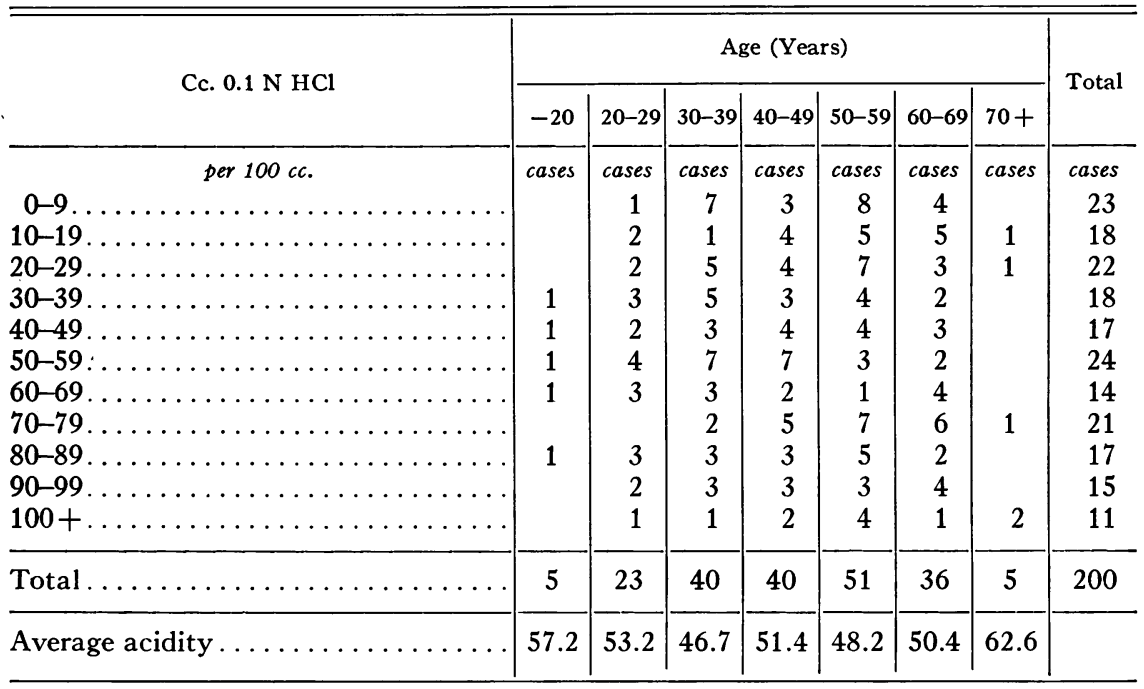

Standard deviation of acidity $=30.7$

Standard deviation of age $=14.3$ 
$-0.015 \pm 0.048$ for free acid and $+0.009 \pm 0.048$ for total acid, values which are not significant.

The incidence of anacidity was 13.0 per cent, of hypoacidity 16.5 per cent, of normal acidity 49.5 per cent and of hyperacidity 21.0 per cent. The results for the incidence of achlorhydria with age are extremely interesting and are represented graphically in Figure 1. The unusual finding was the low incidence of anacidity in the age groups of 65 and over, i.e. 5.3 per cent of the 19 cases in these groups. Taking the data as a whole we find there is no significant correlation between age and incidence of anacidity. However, as the chart illustrates there is a definite

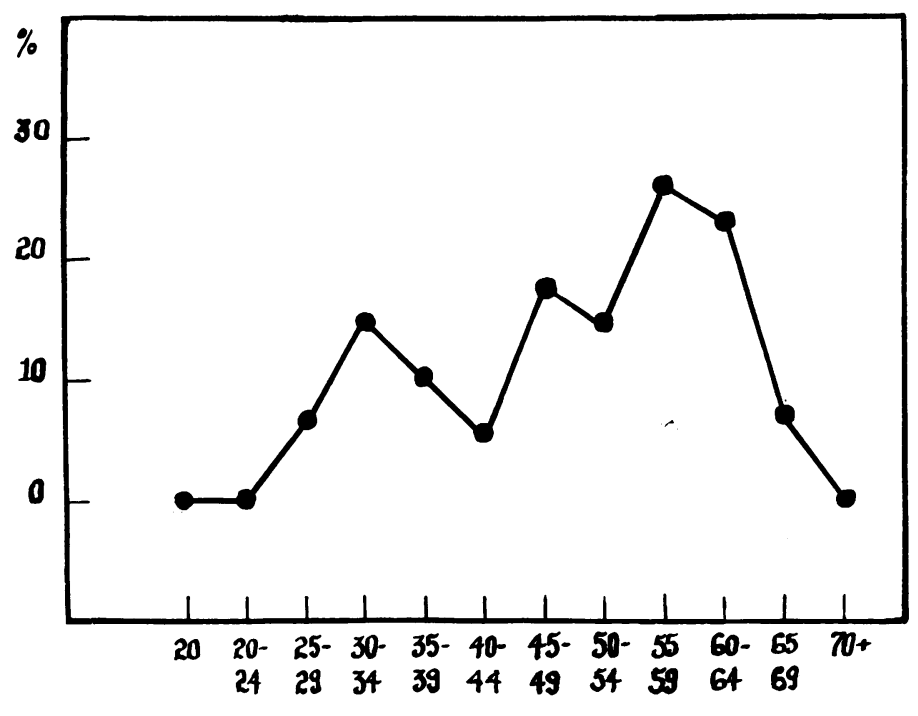

RGE (YEARS)

Fig. 1. The Percentage Incidence of Achlorhydria in Normal People in Different Age Groups

increase in the incidence up to the age of 65 . Of the 28 cases under 30 years of age 3.6 per cent showed achlorhydria, whereas 24.4 per cent of the 45 cases belonging in the age groups of 55-64 revealed this same finding. The coefficient of correlation between the incidence of achlorhydria and age (up to 65 years) is $+0.85 \pm 0.062$, a very significant one. The decrease in incidence after 65 years is difficult to explain. Vanzant (4) makes the interesting suggestion that the mortality rate may be higher in persons with achlorhydria than in those with free acid in the stomach. These older people also showed a tendency to hypersecretion. For example, the incidence of hyperacidity in the age groups under 65 was 19.3 per cent, with relatively slight fluctuation in the different age groups, whereas over 65 it was 36.8 per cent. 
The preceding results are not in accord with the data of other investigators. For example, Bloomfield and Keefer (9), using an alcohol test meal, and Polland and Bloomfield (5), using histamine, found a definite correlation between acid secretion and age. The former workers also noted an increased incidence of achlorhydria with advancing age. Our results agree qualitatively with those of Vanzant (4).

As indicated in another communication (10) there is a striking difference in the gastric secretion of the sexes. Figure 2 shows that the average secretion of free acid by age was usually higher in the male than in the female, but after the age of 50 the tendency was towards equal values. The average free acidity for the male was $44.7 \pm 1.91 \mathrm{cc}$. and for the fe-

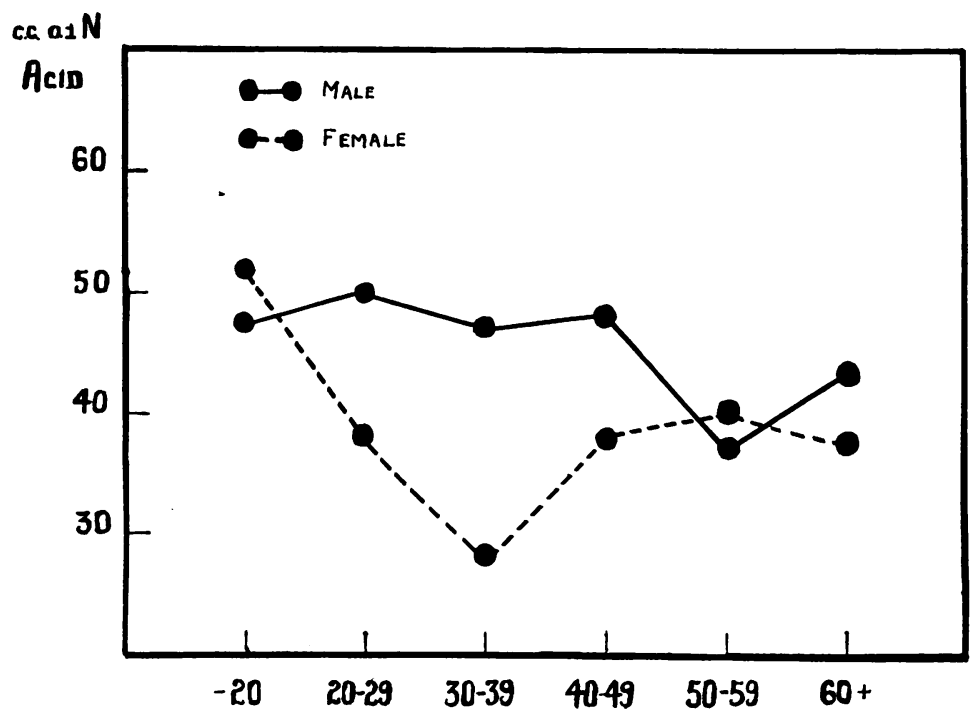

Age Grdups (YrS)

Fig. 2. The Average Secretion of Free Acid of Normal Male and Female Patients According to Age

male $36.8 \pm 1.86 \mathrm{cc}$., a difference of $7.9 \pm 2.67 \mathrm{cc}$. This value is definitely significant because it is about three times its probable error. There was no correlation between acidity and age in each sex. The increase in achlorhydria was present in both sexes, but to a relatively greater degree in the male.

The sex differences may also be demonstrated by comparing the incidence of the various degrees of free acidity.

\begin{tabular}{|c|c|c|}
\hline & $\underset{\text { per cent }}{\text { Male (90) }}$ & $\underset{\text { per cent }}{\text { Female (110) }}$ \\
\hline Anacidity & $\ldots 10.0$ & 15.4 \\
\hline idity. & ..11.1 & 20.9 \\
\hline Normal acidity & .55 .6 & 44.5 \\
\hline Hyperacidity. & .23 .3 & 19.2 \\
\hline
\end{tabular}


These results indicate that females more frequently have anacidity and hypoacidity, and less of ten hyperacidity. Mathematically, the odds are 8 to 1 against the occurrence of such results on the basis of chance alone. In Figure 3 the above percentages are compared graphically. The differences appear even greater because the results for the males have been corrected for age distribution, using the females as standard. It should be noted that the results for total acidity ran parallel with those for free acidity and therefore are not recorded.

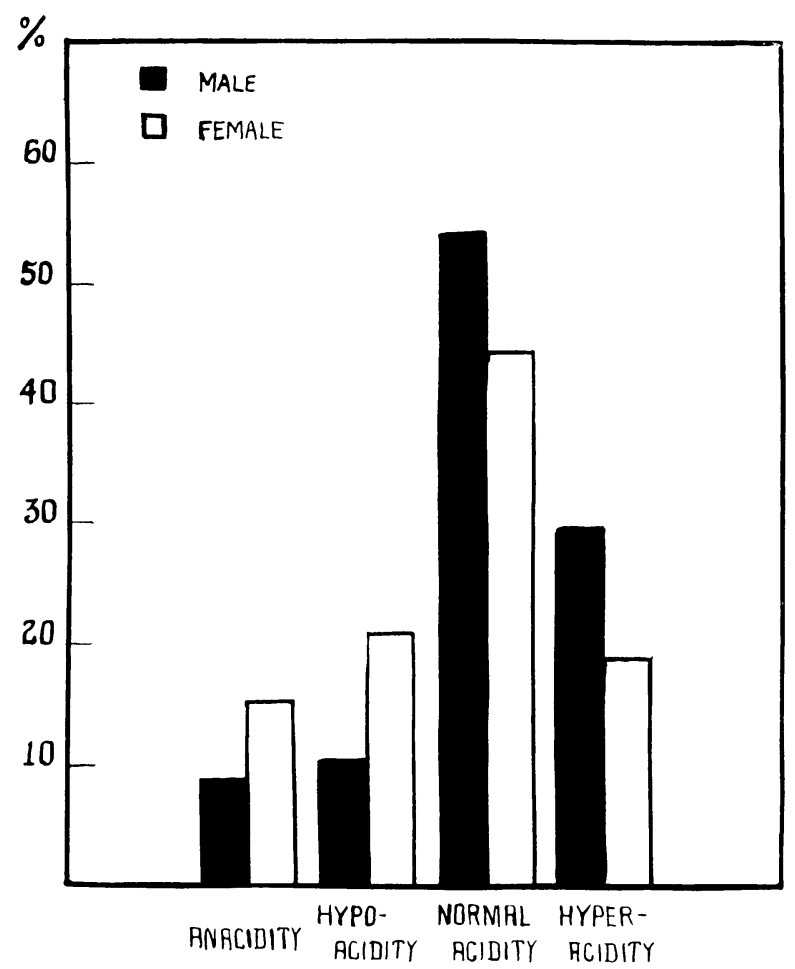

Fí. 3. The Percentake Ixcidexce of the Various I)egrees of Achity in Cormal Male axd Female Patients

The results are corrected for age distribution of males as compared to the females.

An attempt was made to correlate the gastric acidity with the red blood cell count and hemoglobin content. The distribution data for free acidity are given in Tables 3 and 4. It is evident from Figure 4, that the red blood cell count and hemoglobin content tended to vary directly with the average acidity. For example, the average free acidity for the 22 cases with counts under 4 million cells was $31.4 \mathrm{cc}$. and for the 21 cases with counts over 5.5 million cells was $5.3 .3 \mathrm{cc}$. ; the average free acidity $\mathrm{for}$ the 15 cases with hemoglobin values below 60 per cent was $19.7 \mathrm{cc}$. and 
TABLE 3

Distribution of the free acidity of 199 normal subjects according to level of red blood cell count

\begin{tabular}{|c|c|c|c|c|c|c|c|c|}
\hline \multirow{2}{*}{ Cc. $0.1 \mathrm{~N} \mathrm{HCl}$} & \multicolumn{7}{|c|}{ Red blood cell count (Millions) } & \multirow{2}{*}{ Total } \\
\hline & -3.50 & $3.50-3.99$ & $4.00-4.49$ & $4.50-4.99$ & $5.00-5.49$ & $5.50-5.99$ & $6.00+$ & \\
\hline 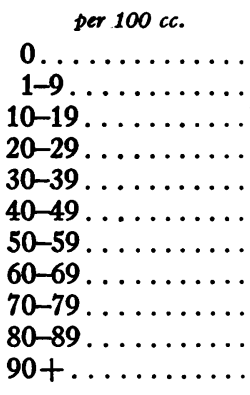 & \begin{tabular}{|c|} 
cases \\
2 \\
1 \\
2 \\
\\
1 \\
1 \\
\\
1 \\
2
\end{tabular} & $\begin{array}{c}\text { cases } \\
2 \\
3 \\
1 \\
2 \\
1 \\
1 \\
2\end{array}$ & $\begin{array}{c}\text { cases } \\
8 \\
4 \\
7 \\
7 \\
2 \\
3 \\
4 \\
4 \\
3 \\
5 \\
3\end{array}$ & $\begin{array}{c}\text { cases } \\
7 \\
3 \\
4 \\
9 \\
4 \\
9 \\
8 \\
2 \\
5 \\
3 \\
2\end{array}$ & $\begin{array}{c}\text { cases } \\
7 \\
3 \\
3 \\
3 \\
6 \\
6 \\
6 \\
5 \\
5 \\
2 \\
4\end{array}$ & $\begin{array}{l}\text { cases } \\
1 \\
2 \\
1 \\
1 \\
3 \\
2 \\
2 \\
1 \\
1 \\
1\end{array}$ & cases & $\begin{array}{r}\text { cases } \\
26 \\
12 \\
21 \\
22 \\
17 \\
23 \\
21 \\
16 \\
17 \\
13 \\
11\end{array}$ \\
\hline Total .......... & 10 & 12 & 50 & 56 & 50 & 15 & 6 & 199 \\
\hline Average acidity... & 32.2 & 30.8 & 37.4 & 38.8 & 42.8 & 47.4 & 68.0 & \\
\hline
\end{tabular}

Standard deviation of acidity $\quad=28.4$

Standard deviation of red blood cell count $=0.64$

TABLE 4

Distribution of the free acidity of 198 normal subjects according to hemoglobin levels

\begin{tabular}{|c|c|c|c|c|c|c|c|}
\hline \multirow{2}{*}{ Cc. $0.1 \mathrm{~N} \mathrm{HCl}$} & \multicolumn{6}{|c|}{ Hemoglobin (Per cent) } & \multirow{2}{*}{ Total } \\
\hline & -50 & $50-59$ & $60-69$ & 70-79 & $80-89$ & $90+$ & \\
\hline 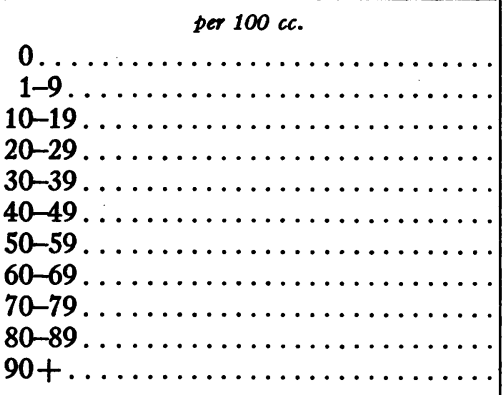 & $\begin{array}{c}\text { cases } \\
3 \\
1 \\
2 \\
1 \\
1\end{array}$ & $\begin{array}{c}\text { cases } \\
3 \\
1 \\
1 \\
1\end{array}$ & $\begin{array}{c}\text { cases } \\
5 \\
3 \\
5 \\
2 \\
6 \\
2 \\
4 \\
2 \\
1 \\
1\end{array}$ & $\begin{array}{c}\text { cases } \\
4 \\
5 \\
3 \\
6 \\
3 \\
7 \\
9 \\
6 \\
3 \\
5 \\
3\end{array}$ & $\begin{array}{c}\text { cases } \\
7 \\
4 \\
9 \\
6 \\
8 \\
5 \\
6 \\
4 \\
7 \\
4 \\
7\end{array}$ & $\begin{array}{c}\text { cases } \\
4 \\
2 \\
3 \\
5 \\
2 \\
4 \\
3 \\
2 \\
4 \\
2\end{array}$ & $\begin{array}{r}\text { cases } \\
26 \\
12 \\
21 \\
22 \\
17 \\
23 \\
21 \\
16 \\
17 \\
12 \\
11\end{array}$ \\
\hline Total ............... & 9. & 6 & 31 & 54 & 67 & 31 & 198 \\
\hline Average acidity . . & 20.6 & 18.1 & 38.3 & 44.2 & 42.9 & 37.7 & \\
\hline
\end{tabular}

Standard deviation of acidity $=28.3$

Standard deviation of hemoglobin $=12.5$ 
for the 98 cases with hemoglobin values of 80 per cent or over was 41.3 cc. The coefficient of correlation between the free acidity and red blood cell count is $+0.195 \pm 0.046$, or 4.2 times its probable error; between the free acidity and hemoglobin content the coefficient is $+0.123 \pm 0.047$, or 2.6 times its probable error. The former is highly significant but the latter only probably so. The corresponding coefficients for total acidity are $+0.205 \pm 0.046$ and $+0.141 \pm 0.047$ respectively. These correlations apply to all levels of acidity, a fact which is more clearly demonstrated in Tables 5 and 6 . These tables condense and summarize the

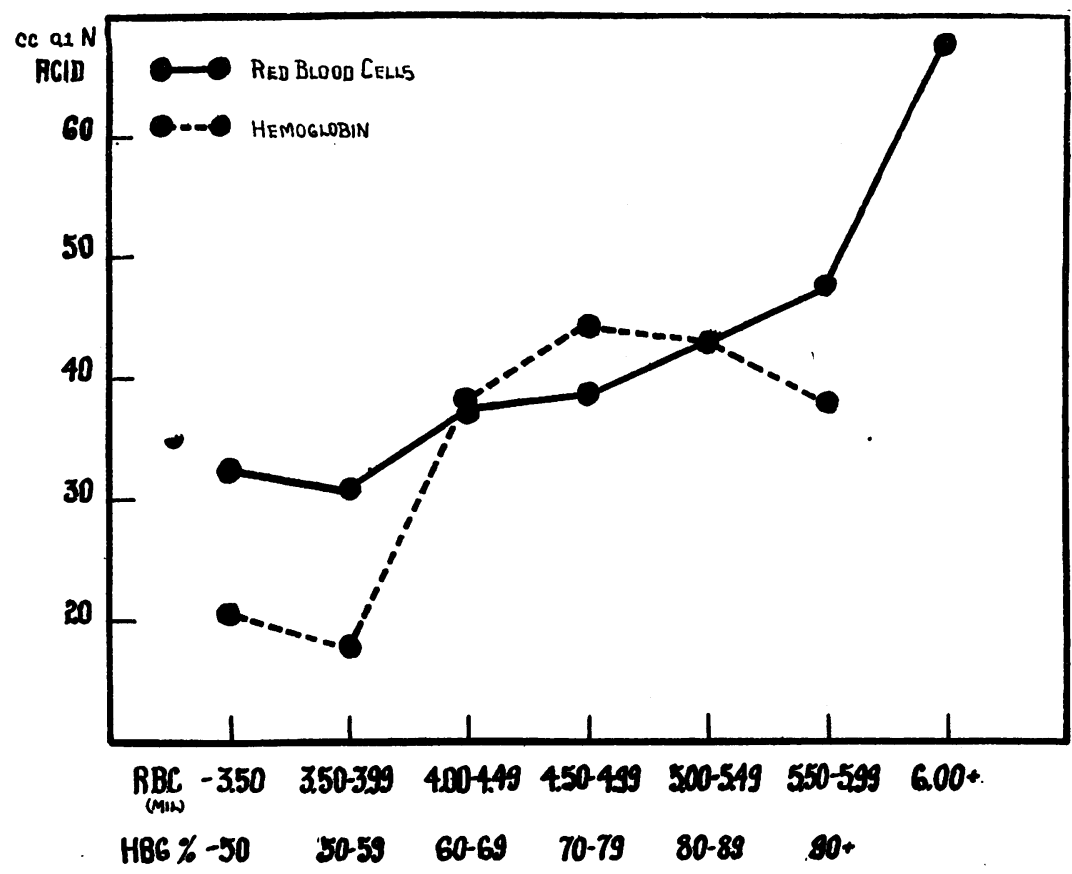

Fig. 4. The Average free Acidity of Normal People According to the levels of Red Blood Cell Count and Hemoglobin Content

TABLE 5

The percentage incidence of the various degrees of free acidity in relation to red blood cell count

\begin{tabular}{|c|c|c|c|c|c|}
\hline & \multicolumn{5}{|c|}{ Red blood cells (Millions) } \\
\hline & -4.00 & $4.00-4.49$ & $4.50-4.99$ & $5.00-5.49$ & $5.50+$ \\
\hline- & $\begin{array}{l}\text { per cent } \\
\text { of cases }\end{array}$ & $\begin{array}{l}\text { per cent } \\
\text { of cases }\end{array}$ & $\begin{array}{l}\text { per cent } \\
\text { of cases }\end{array}$ & $\begin{array}{l}\text { per cent } \\
\text { of cases }\end{array}$ & $\begin{array}{l}\text { per cent } \\
\text { of cases }\end{array}$ \\
\hline $\begin{array}{l}\text { Anacidity } \ldots \ldots \ldots \ldots \ldots \ldots \ldots \ldots \\
\text { Hypoacidity } \ldots \ldots \ldots \ldots \ldots \ldots \ldots \\
\text { Normal acidity } \ldots \ldots \ldots \ldots \ldots \ldots \\
\text { Hyperacidity } \ldots \ldots \ldots \ldots \ldots\end{array}$ & $\begin{array}{r}18.2 \\
27.3 \\
45.5 \\
9.1\end{array}$ & $\begin{array}{l}16.0 \\
22.0 \\
40.0 \\
22.0\end{array}$ & $\begin{array}{l}12.5 \\
12.5 \\
57.1 \\
17.9\end{array}$ & $\begin{array}{l}14.0 \\
12.0 \\
52.0 \\
22.0\end{array}$ & $\begin{array}{c}0 \\
14.3 \\
52.4 \\
33.3\end{array}$ \\
\hline
\end{tabular}


TABLE 6

The percentage incidence of the various degrees of free acidity in relation to hemoglobin

\begin{tabular}{|c|c|c|c|c|c|}
\hline \multirow{2}{*}{ - } & \multicolumn{5}{|c|}{ Hemoglobin (Per cent) } \\
\hline & -60 & $60-69$ & $70-79$ & $80-89$ & $90+$ \\
\hline & $\begin{array}{l}\text { per cent } \\
\text { of cases }\end{array}$ & $\begin{array}{l}\text { per cent } \\
\text { of cases }\end{array}$ & $\begin{array}{l}\text { per cent } \\
\text { of cases }\end{array}$ & $\begin{array}{l}\text { per cent } \\
\text { of cases }\end{array}$ & $\begin{array}{l}\text { per cent } \\
\text { of cases }\end{array}$ \\
\hline Anacidity... & 40.0 & 16.1 & 7.4 & 10.4 & 12.9 \\
\hline Hypoacidity. & 26.7 & 9.7 & 14.8 & 19.4 & 16.1 \\
\hline Normal acidity.. & 26.7 & 61.3 & 57.4 & 43.3 & 51.6 \\
\hline Hyperacidity............. & 6.7 & 12.9 & 20.4 & 26.9 & 19.4 \\
\hline
\end{tabular}

data of Tables 3 and 4 respectively. We see that the incidence of anacidity in the cases with red blood cell counts under 4 million was 18.2 per cent and 0 per cent in the cases with counts of 5.5 million and over; in the cases with hemoglobin values under 60 , the incidence was 40.0 per cent against 11.2 per cent for the cases with hemoglobin values of 80 or over. In general the greater the tendency to achlorhydria, the lower the red blood cell count or hemoglobin content; the greater the tendency to hyperchlorhydria, the higher the red blood cell count or hemoglobin content.

We have also attempted to correlate the gastric acidity with the basal metabolic rate. The results of one or more basal metabolic rates were available in only 41 cases. It is difficult to draw definite conclusions on the basis of this small group. In general, there were large fluctuations in the average free acidity at different levels of metabolism, but there was no discernible trend. The incidence of anacidity seemed to vary to some extent with the level of metabolism as shown in the following tabulation:

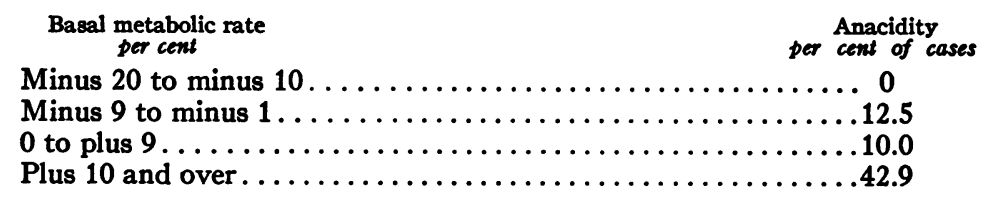

\section{DISCUSSION}

It is always difficult to select individuals who can be considered normal. As previously stated we were careful to exclude any individual who was suffering from any disease which might affect the gastric secretion. However, we included cases with mild gastro-intestinal symptoms when the other findings showed that these symptoms were not significant. Achlorhydria, by itself, was not considered sufficient cause to exclude a case from the normal group. In order to determine whether or not our method of selection caused any errors in the data, we chose a strictly normal group out of the 200 "so-called" normal cases. These patients, 51 
in number, had no gastro-intestinal symptoms whatsoever. The data of their gastric analyses were studied as above and found to be similar to those of the larger group. For example the average free acidity was 41.3 cc. of 0.1 normal acid and the average total acidity $52.6 \mathrm{cc}$. The incidence of achlorhydria was 11.8 per cent compared with 13.0 per cent for the larger group.

Therefore it would seem that a patient, considered to have a normal gastric mucosa clinically, and free from gastro-intestinal complaints, may still show a lack of free hydrochloric acid in his gastric secretion. Polland and Bloomfield (5), however, make the assumption that an organic lesion of the mucosa must exist in these cases, and consequently exclude them from their normal series. There is statistical evidence to show that these cases with anacidity are abnormal because their number is larger than would be expected on the basis of the distribution curve of gastric acidity. Duodenal regurgitation does not account for the large number of cases of anacidity because bile tinged gastric contents were no more frequent in this group than in the group with free acid.

\section{CONCLUSIONS}

1. In a series of gastric analyses of 200 normal patients, using histamine and alcohol as the gastric secretory stimulants, the average free acidity was $40.4 \mathrm{cc}$. of 0.1 normal acid and the average total acidity $50.1 \mathrm{cc}$. There was no correlation between age and gastric acidity.

2. The incidence of anacidity was 13.0 per cent. Up to the age of 65 there was a definite correlation between age and the incidence of anacidity. Beyond this age the number of cases with anacidity dropped off and the number with hyperacidity increased.

3. The average gastric acidity was higher in the male than in the female. Consequently females more frequently show anacidity and hypoacidity and less often hyperacidity.

4. The red blood cell count and hemoglobin content tended to vary directly with the level of gastric acidity. Consequently the greater the tendency to achlorhydria, the lower the red blood cell count and hemoglobin content; the greater the tendency to hyperchlorhydria, the higher the red blood cell count and hemoglobin content.

5. From the data available in 41 cases it seemed that there was some degree of correlation between the incidence of gastric anacidity and level of basal metabolism. 


\section{BIBLIOGRAPHY}

1. Gompertz, L. M., and Vorhaus, M. G., J. Lab. and Clin. Med., 1925, xi, 14. Studies on the Action of Histamine on Human Gastric Secretion.

2. Bockus, H. L., and Bank, J., Arch. Int. Med., 1927, xxxix, 508. The Value of Histamine as a Test for Gastric Function.

3. Davies, D. T., and James, T. G. I., Quart. J. Med., 1930, xxiv, 1. An Investigation into the Gastric Secretion of a Hundred Normal Persons over the Age of Sixty.

4. Vanzant, F. R., Proc. of the Staff Meetings of the Mayo Clinic, 1931, vi, 297. The Normal Range of Gastric Acidity from Youth to Old Age: An Analysis of 3,746 Records.

5. Polland, W. S., and Bloomfield, A. L., J. Clin. Invest., 1931, ix, 651. Normal Standards of Gastric Function.

6. Polland, W. S., Roberts, A. M., and Bloomfield, A. L., J. Clin. Invest., 1928, v, 611. The Chloride, Base and Nitrogen Content of Gastric Juice, After Histamine Stimulation.

7. Henning, N., München. Med. Wchnschr., 1928, lxxv, 1752. Histaminprobe und Prognostik der Achylien.

8. Comfort, M. W., and Osterberg, A. E., Proc. Staff Meet., Mayo Clinic, 1931, vi, 395. Gastric Secretion after Stimulation with Histamine in the Presence of Various Types of Gastric and Duodenal Lesions.

9. Bloomfield, A. L., and Keefer, C. S., J. Clin. Invest., 1928, v, 285. Gastric Acidity; Relation to Various Factors Such as Age and Physical Fitness.

10. Lerman, J., and Means, J. H., Read before the American Association for the Study of Goiter, April 7-9, 1931, Kansas City, Mo. To appear in abstract form in the Proc. of this Association (in press). The Gastric Secretion in Exophthalmic Goitre and Myxoedema. 